\title{
INVESTIGATION ON OPTICAL AND PHOTOELECTROCHEMICAL PROPERTIES OF SELF-ASSEMBLED TITANIA NANOTUBE ARRAYS PREPARED BY ANODIZATION
}

\author{
(Penyiasatan Sifat Optik dan Fotoelektrokimia Swahimpunan Nanotiub Titania \\ Bertatasusunan yang Disediakan Melalui Penganodan) \\ Lim Ying Chin ${ }^{1 *}$, Zulkarnain Zainal ${ }^{2}$, Mohd Zobir Hussein $^{3}$, Tan Wee Tee ${ }^{2}$ \\ ${ }^{1}$ School of Chemistry and Environment, Faculty of Applied Sciences, \\ Universiti Teknologi MARA (UiTM), 40450 Shah Alam, Selangor, Malaysia \\ ${ }^{2}$ Department of Chemistry, Faculty of Science \\ ${ }^{3}$ Advanced Materials and Nanotechnology Laboratory, Institute of Advanced Technology (ITMA) \\ Universiti Putra Malaysia, 43400 UPM Serdang, Selangor, Malaysia \\ *Corresponding author: limyi613@salam.uitm.edu.my
}

Received: 9 December 2014; Accepted: 16 November 2015

\begin{abstract}
Well ordered and vertically oriented titania nanotubes (TNT) are of great scientific interest due to their high surface area, fewer interfacial grain boundaries and excellent charge transfer between interfaces; all are critical properties in photoelectrochemical and photocatalysis application. In this study, self-assembled TNT electrodes were synthesized by anodization of pure Ti in 0.5 wt.\% $\mathrm{NH}_{4} \mathrm{~F}$ solution $\left(\mathrm{NH}_{4} \mathrm{~F} / \mathrm{H}_{2} \mathrm{O}\right)$, in mixture of aqueous-organic solution $\left(\mathrm{NH}_{4} \mathrm{~F} / \mathrm{H}_{2} \mathrm{O} / \mathrm{EG}\right)$ and in an organic solution $\left(\mathrm{NH}_{4} \mathrm{~F} / \mathrm{EG}\right)$. Choice of electrolytic medium has an influence on the crystalline structure, regularity, elemental composition and band gap of TNT. All the samples showed a red shift and stronger absorption in the wavelength between 500-700 nm ascribed to the surface colour and increase crystallinity upon calcination. TNT formed in $\mathrm{NH}_{4} \mathrm{~F} / \mathrm{H}_{2} \mathrm{O}$ solution has the highest direct band gap of $3.34 \mathrm{eV}$ due to quantization effect. From Liner Sweep Photovoltammetry analysis, the lowest photocurrent was recorded for TNT anodized in $\mathrm{NH}_{4} \mathrm{~F} / \mathrm{H}_{2} \mathrm{O}$ and a twofold and fivefold increase on the magnitude of photocurrent was obtained for those formed in $\mathrm{NH}_{4} \mathrm{~F} / \mathrm{H}_{2} \mathrm{O} / \mathrm{EG}$ and $\mathrm{NH}_{4} \mathrm{~F} / \mathrm{EG}$ solution, respectively. Hence, highest photoefficiency of $2.79 \%$ was recorded for TNT formed in $\mathrm{NH}_{4} \mathrm{~F} / \mathrm{EG}$ probably due to the formation of longer length tube.
\end{abstract}

Keywords: titania, nanotube, anodization, photoefficiency, band gap energy

\section{Abstrak}

Nanotiub titanium dioksida yang bertertib rapi dan berorientasi mencancang (TNT) telah menarik perhatian disebabkan luas permukaan yang tinggi, sempadan butiran antara muka yang rendah dan pemindahan cas yang cemerlang di antara muka, yang mana semua ini merupakan ciri - ciri kritikal dalam aplikasi fotoelektrokimia and fotopemangkinan. Dalam kajian ini, swahimpunan TNT telah disintesis melalui penganodan plat titanium tulen dalam larutan 0.5 wt. $\% \mathrm{NH}_{4} \mathrm{~F}\left(\mathrm{NH}_{4} \mathrm{~F} / \mathrm{H}_{2} \mathrm{O}\right)$, campuran larutan akua-organik $\left(\mathrm{NH}_{4} \mathrm{~F} / \mathrm{EG} / \mathrm{H}_{2} \mathrm{O}\right)$ dan larutan organik $\left(\mathrm{NH}_{4} \mathrm{~F} / \mathrm{EG}\right)$. Pilihan media elektrolisis memberi kesan ke atas struktur hablur, keteraturan, komposisi unsur dan julang jalur TNT. Semua sampel mempamerkan anjakan merah dan penyerapan yang lebih kuat dalam julat gelombang $500-700 \mathrm{~nm}$ disebabkan warna permukaan sampel dan peningkatan kehabluran selepas pemanasan. Dari analisis fotovoltammetri pengimbasan linear, TNT yang teranod dalam larutan $\mathrm{NH}_{4} \mathrm{~F} / \mathrm{H}_{2} \mathrm{O}$ mencatatkan fotoarus yang terendah manakala peningkatan lipat ganda dua dan ganda lima dalam magnitud fotoarus boleh didapati untuk TNT yang teranod dalam larutan $\mathrm{NH}_{4} \mathrm{~F} / \mathrm{H}_{2} \mathrm{O} / \mathrm{EG}$ dan $\mathrm{NH}_{4} \mathrm{~F} / \mathrm{EG}$. Oleh yang demikian, TNT yang dibentuk dalam latutan $\mathrm{NH}_{4} \mathrm{~F} / \mathrm{EG}$ mencatatkan kecekapan foto yang tertinggi sebanyak $2.79 \%$ mungkin disebabkan oleh pembentukan tiub yang lebih panjang. 


\section{Lim et al: INVESTIGATION ON OPTICAL AND PHOTOELECTROCHEMICAL PROPERTIES OF SELF- ASSEMBLED TITANIA NANOTUBE ARRAYS PREPARED BY ANODIZATION}

Kata kunci: titania, nanotiub, penganodan, kecekapan foto, jalur jurang tenaga

\section{Introduction}

Titania $\left(\mathrm{TiO}_{2}\right)$ appears to be the most promising material to be used in photoelectrochemical applications due to its high efficiency, low cost, chemical inertness and photostability [1 - 4]. However, bulk $\mathrm{TiO}_{2}$ materials have low surface area and therefore exhibit low adsorption property. Moreover, fast recombination rate of the photogenerated charge carriers deteriorate the performance of such materials especially in photoelectrochemical applications. In order to overcome such problems, much effort has been focused on fabrication of highly efficient materials with suitable architecture to minimize the recombination of electron-hole pairs. In this context, formation of highly ordered and oriented nanotubular or porous geometry is advantageous due to high surface-to-volume ratio and short diffusion path within enclosed nanoscale compartment [5]. Self-organized growth of $\mathrm{TiO}_{2}$ nanotube arrays are of great interest due to its unique physical properties including larger surface area in a small geometrical area, fewer interfacial grain boundaries and superior charge transport, of which all are important properties governing its performance as photoanode in a photoelectrochemical cell. Therefore, the study aimed at synthesizing titania nanotubes in various electrolytic compositions in order to investigating the effects of electrolyte nature on the microstructure, optical and photoelectrochemical performance of the synthesized TNT.

\section{Fabrication of titania nanotube arrays}

\section{Materials and Methods}

A Ti foil (99.7\%, Sigma Aldrich) was used for producing vertically oriented nanotubes. Prior to anodization, the Ti foils were cleaned by sonication in acetone, isopropanol, and deionized (DI) water respectively, followed by subsequent etching in $6 \mathrm{M} \mathrm{HNO}_{3}$. They were then rinsed with DI water and dried in air. An electrochemical cell with a two-electrode configuration was used. The Ti foil served as the working electrode and high density graphite was used as the counter electrode and they were separated by approximately $2 \mathrm{~cm}$. All the experiments were driven by a DC power source (Consort Mini, Cleaver Scientific Ltd) and were carried out at room temperature in three different types of electrolytes for 2 hours to form TNT. The composition of the three electrolyte solutions and voltage used for anodization were summarized in Table 1. After the anodization process, the samples were rinsed with DI water and dried in air. Subsequently, they were calcined at $500{ }^{\circ} \mathrm{C}$ in air for 2 hours with a heating rate of 2 ${ }^{\circ} \mathrm{C} /$ minutes. The resultant calcined TNT are hereinafter designated as $\mathrm{C} 5 \mathrm{TNT} / \mathrm{H}_{2} \mathrm{O}$, for the $0.5 \mathrm{wt} \% \mathrm{NH}_{4} \mathrm{~F}$ solution adjusted to $\mathrm{pH} 4, \mathrm{C} 5 \mathrm{TNT} / \mathrm{EGH}_{2} \mathrm{O}$, for the mixture of ethylene glycol containing 50 vol. $\% \mathrm{H}_{2} \mathrm{O}$ and $0.5 \mathrm{wt} . \% \mathrm{NH}_{4} \mathrm{~F}$ and C5TNT/EG, for ethylene glycol containing $0.5 \mathrm{wt} . \% \mathrm{NH}_{4} \mathrm{~F}$. For comparison, the as-anodized samples without heat treatment were produced and were designated as AOTNT/ $\mathrm{H}_{2} \mathrm{O}, \mathrm{AOTNT} / \mathrm{EGH}_{2} \mathrm{O}$ and AOTNT/EG, respectively.

Table 1. Summary of electrolyte compositions and voltage used producing TNT during anodization

\begin{tabular}{lcc}
\hline Samples & Electrolyte composition & Voltage / V \\
\hline TNT/ $\mathrm{H}_{2} \mathrm{O}$ & 0.5 wt. $\% \mathrm{NH}_{4} \mathrm{~F}$ adjusted to $\mathrm{pH} 4$ & 20 \\
$\mathrm{TNT} / \mathrm{EGH}_{2} \mathrm{O}$ & 0.5 wt. $\% \mathrm{NH}_{4} \mathrm{~F}+$ ethylene glycol +50 vol. $\% \mathrm{H}_{2} \mathrm{O}$ & 20 \\
$\mathrm{TNT} / \mathrm{EG}$ & 0.5 wt. $\% \mathrm{NH}_{4} \mathrm{~F}+$ ethylene glycol & 65 \\
\hline
\end{tabular}

\section{Characterization of titania nanotube arrays}

Phase identification was carried out using an X-ray diffractometer (XRD, Shimadzu D6000) with $\mathrm{Cu}_{\alpha} \mathrm{K}_{\alpha}$ radiation $(\lambda=1.5406 \AA)$. The morphology of the samples was characterized on TEM Hitachi H-1700 operating at an accelerating voltage of $200 \mathrm{kV}$. Quantitative measurements were done using image analysis software (Image J). Energy dispersive analysis of x-rays (EDX) was performed on JOEL FESEM JSM-7600F JOEL, Japan attached with Oxford INCA Energy 200 EDX to determine the purity and elemental composition in the as-anodized and 
calcined samples. The optical absorbance behavior of TNT was characterized using a diffuse reflectance UV-VISNIR spectrophotometer (Model: UV-3600, Shimadzu Corporation, Kyoto, Japan) equipped with an integration sphere. $\mathrm{BaSO}_{4}$ was used as a reflectance standard. The band gap energy $\left(\mathrm{E}_{\mathrm{g}}\right)$ can be calculated using the absorbance data obtained following the Tauc Plot relation (Equation 1):

$$
\alpha h v=\mathrm{A}\left(\mathrm{h} v-\mathrm{E}_{\mathrm{g}}\right)^{\mathrm{n}}
$$

where $\alpha$ is the absorption coefficient, $h$ is the Planck's constant, $v$ is the wavenumber and $A$ is a constant. The " $n$ " depends on the types of band-to-band transition (for titania, $n=2$ for a direct band gap and $n=1 / 2$ for a indirect transition between bands). The band gap energy could be obtained by extrapolating the straight line in the plot of $\alpha^{1 / 2}$ or $\alpha h v^{2}$ against $h v$ to the base line where $\alpha^{1 / 2}$ or $\alpha h v^{2}=0$. Thus, the $\mathrm{E}_{\mathrm{g}}$ is equivalent to $h v$.

\section{Photoelectrochemical test}

Photoelectrochemical response of TNT was demonstrated using a three-electrode system with the synthesized TNT as the working electrode, a platinum wire as the counter electrode, and $\mathrm{Ag} / \mathrm{AgCl}$ as the reference electrode. The photocurrent was measured with a scanning potentiostat ( $\mu$ Autolab type III) during a voltage sweep from +2.0 to $-0.2 \mathrm{~V}$ with the sweep rate of $20 \mathrm{mV} / \mathrm{s}$ in $10 \mathrm{ppm}$ methyl orange with $0.1 \mathrm{M} \mathrm{KCl}$ as the supporting electrolyte. All the potentials were quoted against $\mathrm{Ag} / \mathrm{AgCl}$ reference electrode. A tungsten halogen lamp $(300 \mathrm{~W}, 120 \mathrm{~V})$ was used for illuminating the TNT samples and the light was intermittently chopped at a constant frequency to evaluate both the photocurrent and dark current. A UV lamp (B-100AP) with the incident power of $11 \mathrm{~mW} / \mathrm{cm}^{2}$ was used to evaluate the efficiency of photocurrent generated by TNT prepared in different electrolytic medium and the radiation source was placed $15 \mathrm{~cm}$ away from the cell. The solution used was $0.1 \mathrm{M} \mathrm{KOH}$

\section{Results and Discussion}

Electrolyte composition is an important parameter influencing the structure, morphology and geometry (and thus the specific surface area) of the resulted nanotubes. The crystallinity and the isomorphs of TNT are critical in influencing their properties and potential applications. Figure 1 illustrates the XRD patterns of TNT as a function of electrolytic medium. No peak shift was observed as a function of electrolytic medium. For TNT/ $\mathrm{H}_{2} \mathrm{O}$, a mixture of anatase at $2 \theta=25.4^{\circ}$ (JCPDS No. 21-1272) and rutile at $2 \theta=27.6^{\circ}$ (JCPDS No. 21-1276) was observed after calcination at $500{ }^{\circ} \mathrm{C}$. As opposed to $\mathrm{TNT} / \mathrm{H}_{2} \mathrm{O}$, only pure anatase phase at $2 \theta=25.4^{\circ}, 38.0^{\circ}, 48.2^{\circ}, 54.0^{\circ}$ and $55.2^{\circ}$ corresponding to (101), (004), (200), (105) and (211) plane, respectively was obtained for TNT/EG and $\mathrm{TNT} / \mathrm{EGH}_{2} \mathrm{O}$ upon calcination at $500{ }^{\circ} \mathrm{C}$ as shown in Figure 1 (b-c). Our finding is in contradiction with the work reported by other researchers that the crystalline structures remained unaffected with different electrolytic media $[6,7]$. It is also discernible that the (101) reflection exhibited greatest intensity as compared to the other anatase peaks for all samples, demonstrating the preferred growth orientation for nanotubes at this plane. For TNT/EG sample, almost tenfold increase on the intensity magnitude of (101) reflection compared to $\mathrm{TNT} / \mathrm{H}_{2} \mathrm{O}$ and a threefold increase for TNT/EGH $2 \mathrm{O}$ sample, probably ascribed to increase in length for samples prepared in different electrolytic medium.

TEM analysis was performed to gain information on the microstructure of the sample. Figure 2 shows the TEM image of all samples. Apparently, a single nanotube consisted of a closed bottom with a barrier layer thickness of 37 $\mathrm{nm}$ and ripples on sidewall were obtained in $\mathrm{NH}_{4} \mathrm{~F} / \mathrm{H}_{2} \mathrm{O}$ solution. Same observation on the formation of ripples was obtained for TNT/EGH $\mathrm{E}_{2} \mathrm{O}$. These ripples could be formed due to current fluctuations occurred during anodization process. In contrast, well-dispersed and straight nanotubes with uniform wall thickness and smooth tube wall throughout the length of the nanotubes can be observed for TNT formed in $\mathrm{NH}_{4} \mathrm{~F} / \mathrm{EG}$. Therefore, the electrolyte composition is a crucial factor determining the morphology of the outer wall where ripples are observed in nanotubes grown in aqueous electrolytes, whereas nanotubes prepared in ethylene glycol can be either smooth or are having ripples depending on the water content ( 50 vol. \% in this study). 


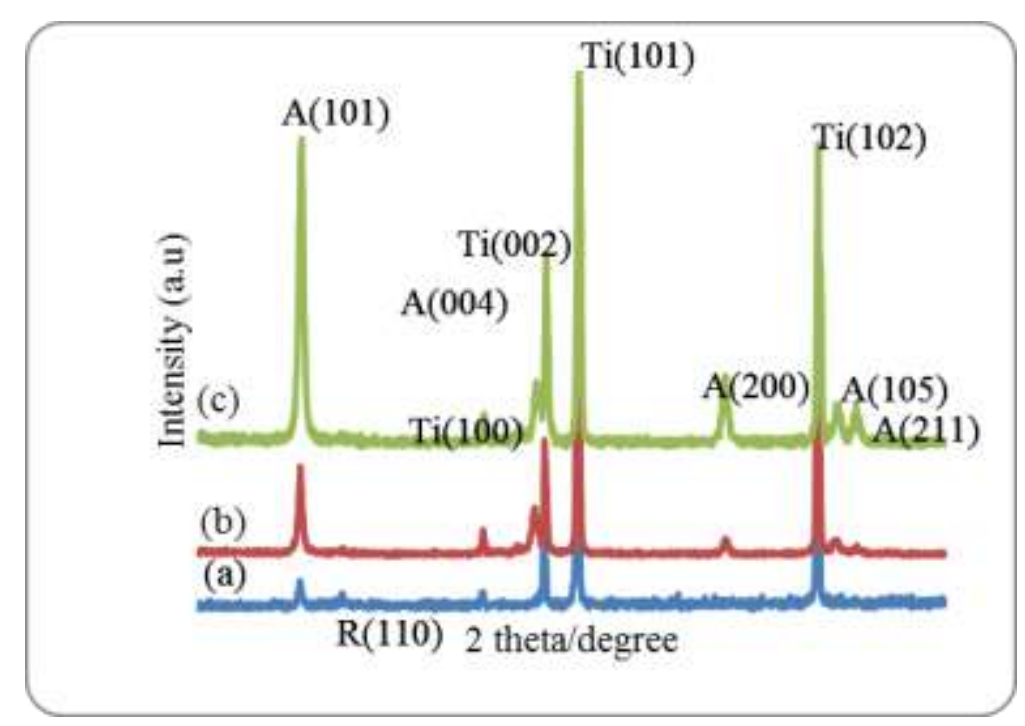

Figure 1. XRD patterns of calcined TNT synthesized at $20 \mathrm{~V}$ in different electrolytic medium with (a) $\mathrm{NH}_{4} \mathrm{~F} / \mathrm{H}_{2} \mathrm{O}$ (b) $\mathrm{NH}_{4} \mathrm{~F} / \mathrm{EG}$ and (c) $\mathrm{NH}_{4} \mathrm{~F} / \mathrm{EG} / \mathrm{H}_{2} \mathrm{O}$ solution. $\mathrm{A}, \mathrm{R}$ and $\mathrm{Ti}$ represent anatase, rutile and titanium, respectively
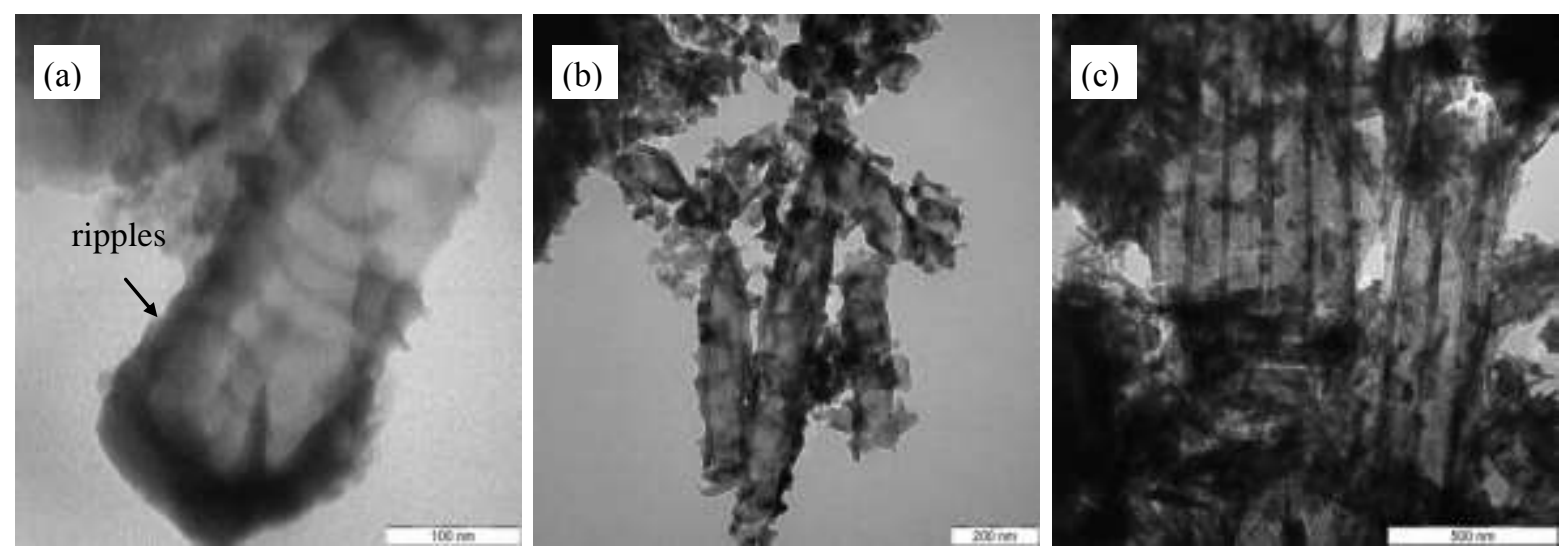

Figure 2. TEM images for (a) $\mathrm{TNT} / \mathrm{H}_{2} \mathrm{O}$ (b) $\mathrm{TNT} / \mathrm{EGH}_{2} \mathrm{O}$ and (c) $\mathrm{TNT} / \mathrm{EG}$

EDX analysis was done on blank Ti plate, as-anodized TNT and their calcined counterparts. The detailed compositions of the samples before and after calcination are shown in Table 2. For blank Ti, only Ti element was detected and $\mathrm{C}$ peak observed is due to carbon tape holding the sample. Evidently, Ti, $\mathrm{O}$ and $\mathrm{F}$ are found in the spectrum for $\mathrm{AOTNT} / \mathrm{H}_{2} \mathrm{O}, \mathrm{AOTNT} / \mathrm{EGH}_{2} \mathrm{O}$ and $\mathrm{AOTNT} / \mathrm{EG}$, with trace of carbon from the ethylene glycol observed for AOTNT/EG sample. The fluorine observed is due to the $\mathrm{NH}_{4} \mathrm{~F}$ added in the solution, which acts as a pore initiating agent. Calcination at $500{ }^{\circ} \mathrm{C}$ leads to a complete loss of the fluorine for C5TNT/EG and thus it is free from fluoride content and this result is similar with the work reported by Sreekantan et al. [8]. However, traces of $\mathrm{F}$ still can be detected for $\mathrm{C} 5 \mathrm{TNT} / \mathrm{H}_{2} \mathrm{O}$ and $\mathrm{C} 5 \mathrm{TNT} / \mathrm{EGH}_{2} \mathrm{O}$ but with almost negligible amount, indicating that the $\mathrm{F}$ is precipitated on the surface of sample during anodization and not incorporated into the $\mathrm{TiO}_{2}$ lattice. In addition, all samples showed an increase in $\mathrm{Ti}$ and $\mathrm{O}$ content upon calcination. The molar ratio of $\mathrm{Ti}$ to $\mathrm{O}$ for calcined samples was close to the stoichiometric proportion, suggesting the samples were $\mathrm{TiO}_{2}$. 
For TNT/EG sample, a carbon rich layer could be probably obtained due to the voltage induced decomposition of the ethylene glycol as high voltage $(65 \mathrm{~V})$ is used during anodization of Ti. Therefore, higher $\mathrm{C}$ content $(2.33 \mathrm{wt} . \%)$ was observed for AOTNT/EG sample. However, no C uptake from the solution occurs for C5TNT/EG given the C weight percent present is comparable to the blank Ti plate upon calcination at $500{ }^{\circ} \mathrm{C}$. This result indicates that $\mathrm{C}$ from the ethylene glycol in AOTNT/EG could be easily removed via thermal treatment.

Table 2. Elemental analysis for Ti, as-anodised TNT and calcined $\mathrm{TNT} / \mathrm{H}_{2} \mathrm{O}, \mathrm{TNT} / \mathrm{EGH}_{2} \mathrm{O}$ and TNT/EG

\begin{tabular}{ccccc}
\hline \multirow{2}{*}{ Sample } & \multicolumn{5}{c}{ Weight percent $(\%)$} \\
\cline { 2 - 5 } & $\mathbf{T i}$ & $\mathbf{O}$ & $\mathbf{C}$ & $\mathbf{F}$ \\
\hline $\mathrm{Ti}$ & 99.44 & - & 0.45 & - \\
$\mathrm{AOTNT} / \mathrm{H}_{2} \mathrm{O}$ & 58.22 & 31.27 & - & 10.51 \\
$\mathrm{AOTNT} / \mathrm{EGH}_{2} \mathrm{O}$ & 51.20 & 38.53 & - & 10.27 \\
$\mathrm{AOTNT} / \mathrm{EG}$ & 46.71 & 35.90 & 2.33 & 15.06 \\
$\mathrm{C} 5 \mathrm{TNT} / \mathrm{H}_{2} \mathrm{O}$ & 61.83 & 36.11 & - & 2.06 \\
$\mathrm{C} 5 \mathrm{TNT} / \mathrm{EGH}_{2} \mathrm{O}$ & 53.30 & 44.22 & - & 2.48 \\
$\mathrm{C} 5 \mathrm{TNT} / \mathrm{EG}$ & 63.11 & 36.60 & 0.29 & - \\
\hline
\end{tabular}

Figure 3 shows the diffuse reflectance UV-Vis absorbance of both the as-anodized and calcined TNT prepared in different electrolytic medium. The absorbance response for AOTNT/ $\mathrm{H}_{2} \mathrm{O}, \mathrm{AOTNT} / \mathrm{EGH}_{2} \mathrm{O}$ and AOTNT/EG exhibited lower absorption in the visible region, whereas the calcined counterparts showed a red shift and stronger absorption in the wavelength between 500-750 nm, with exception for C5TNT/EGH ${ }_{2} \mathrm{O}$. This can be attributed to the surface color and changes in crystalline structure of TNT. Generally, the color of C5TNT/ $\mathrm{H}_{2} \mathrm{O}$ was yellowish, dark green for C5TNT/EGH ${ }_{2} \mathrm{O}$ and dark grey green for C5TNT/EG, respectively. In contrast, the as-anodized films were bright green, bright purple and bright grey for AOTNT/ $\mathrm{H}_{2} \mathrm{O}$, AOTNT/EGH $\mathrm{E}_{2} \mathrm{O}$ and AOTNT/EG, respectively and this causes more adsorption in ultraviolet region and more reflection in the visible region. As shown in Figure 2, the absorption onset for $\mathrm{C} 5 \mathrm{TNT} / \mathrm{H}_{2} \mathrm{O}, \mathrm{C} 5 \mathrm{TNT} / \mathrm{EGH}_{2} \mathrm{O}$ and $\mathrm{C} 5 \mathrm{TNT} / \mathrm{EG}$ was around 370, 380 and 390, respectively which was probably caused by increasing anatase content after thermal treatment. This is consistent with the changes in crystalline structure observed in XRD scan (Figure 1).
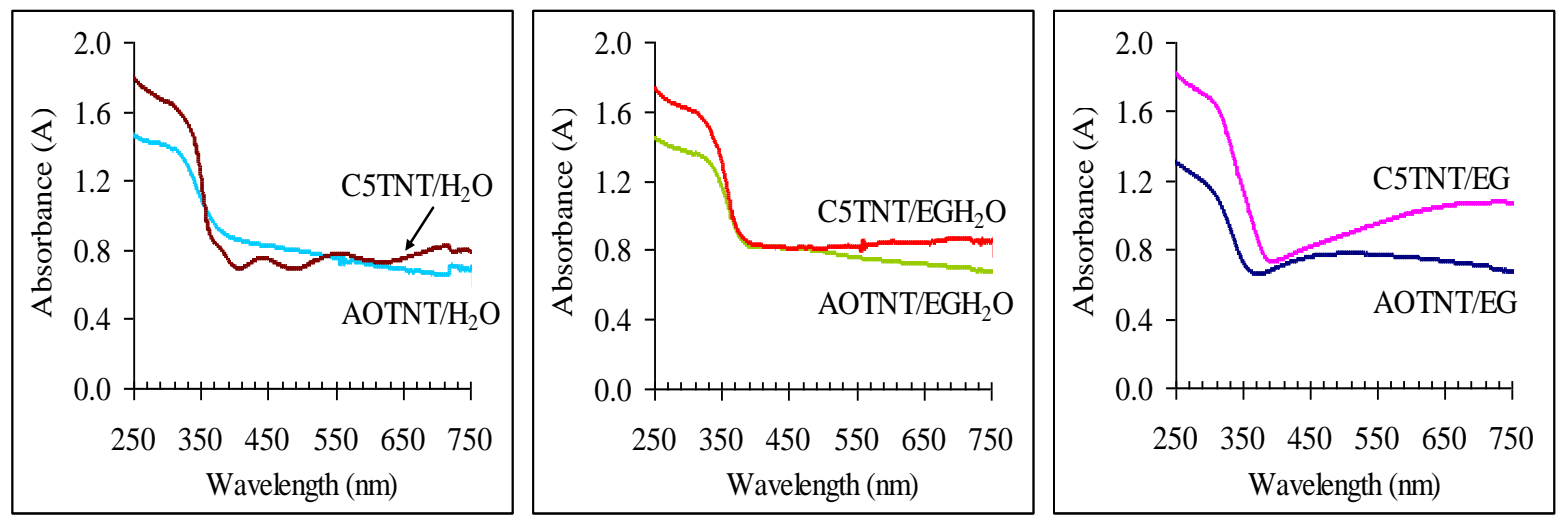

Figure 3. UV-Visible absorbance spectra of TNT/ $\mathrm{H}_{2} \mathrm{O}, \mathrm{TNT} / \mathrm{EGH}_{2} \mathrm{O}$ and TNT/EG sample

In addition, the absorbency of visible light $(<550 \mathrm{~nm})$ is higher for C5TNT/EG sample, which could mean that it possesses a higher efficiency of sunlight utilization compared to $\mathrm{C} 5 \mathrm{TNT} / \mathrm{H}_{2} \mathrm{O}$ and $\mathrm{C} 5 \mathrm{TNT} / \mathrm{EGH}_{2} \mathrm{O}$ sample. It is thus 
expected that C5TNT/EG sample will result in an improvement in solar cell fabrication and in photocatalytic activity. Red shift in absorption wavelength in the visible region for C5TNT/EG might due to oxidation of ethylene glycol to carbonate type species which get adsorbed on the nanotube walls as an outer layer. Sohn et al. [9] also observed the introduction of carbon into TNT, which facilitates the improvement in visible light absorbance when employing ethylene glycol as electrolyte.
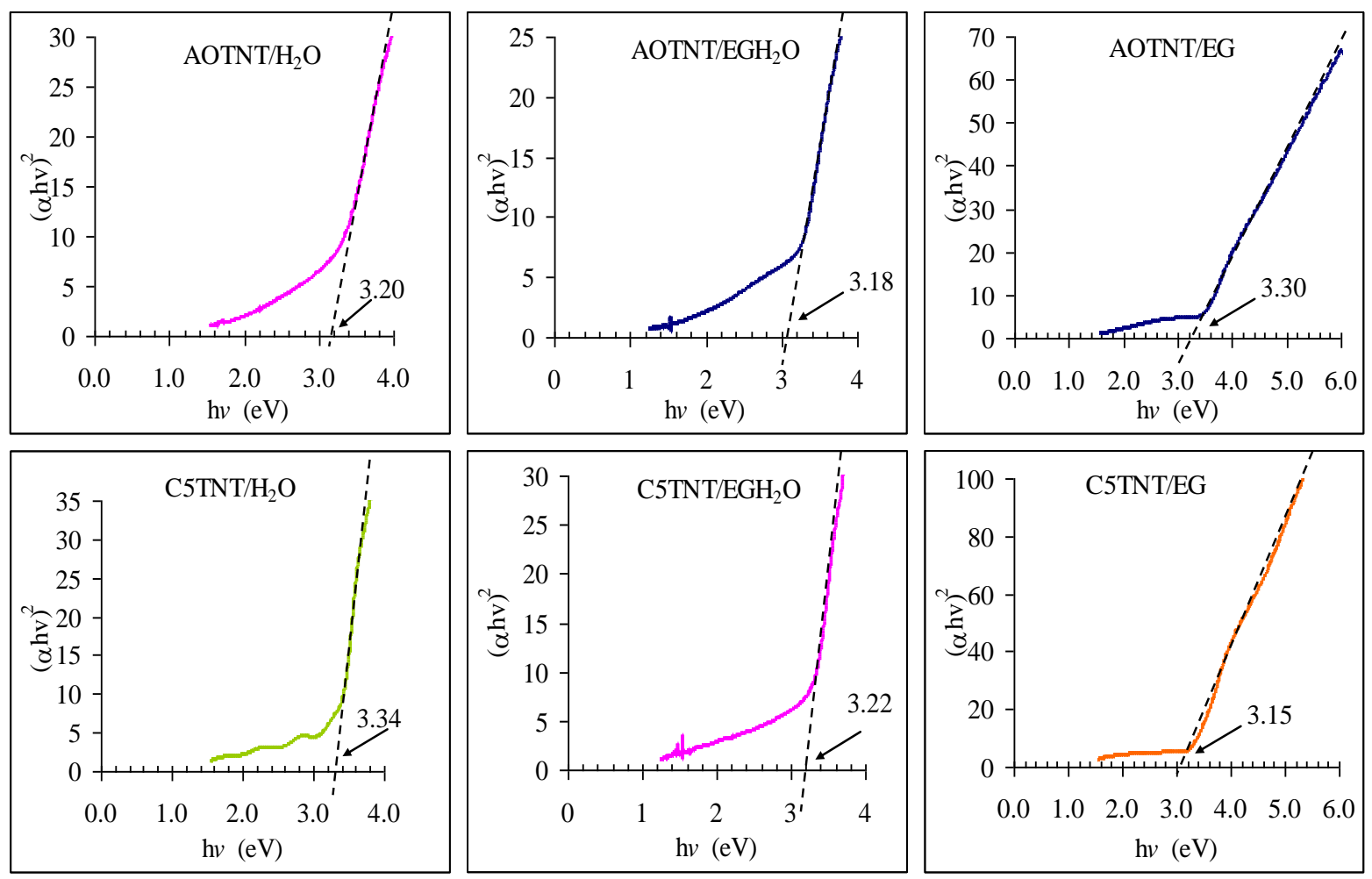

Figure 4. Plot of $(\alpha \mathrm{hv})^{2}$ versus $\mathrm{h} v$ for AOTNT/ $\mathrm{H}_{2} \mathrm{O}, \mathrm{AOTNT} / \mathrm{EGH}_{2} \mathrm{O}$ and AOTNT/EG and their calcined counterparts

Figure 4 shows the plot of $(\alpha h v)^{2}$ versus $h v$ for TNT prepared in different electrolytic medium. All the three asanodised samples, AOTNT/ $\mathrm{H}_{2} \mathrm{O}, \mathrm{AOTNT} / \mathrm{EGH}_{2} \mathrm{O}$ and AOTNT/EG have band gap energy of $3.18-3.30 \mathrm{eV}$ with a direct transition and this result is similar with the work reported by Song et al. [10]. For the calcined samples, C5TNT/ $\mathrm{H}_{2} \mathrm{O}$ has the highest direct band gap of 3.34, which was higher than $3.2 \mathrm{eV}$ for bulk anatase due to quantization effect of the nanosized titania. However, $\mathrm{C} 5 \mathrm{TNT} / \mathrm{EGH}_{2} \mathrm{O}$ and C5TNT/EG exhibited a direct bandgap of 3.22 and $3.15 \mathrm{eV}$ respectively, which was comparable to that of bulk anatase. The calcined samples demonstrated higher band gap than their as-anodised counterpart except for C5TNT/EG sample. From the EDX analysis (Table 2), no carbon was found for both the AOTNT/ $\mathrm{H}_{2} \mathrm{O}$ and $\mathrm{AOTNT} / \mathrm{EGH}_{2} \mathrm{O}$ samples whereas a 2.33 wt.\% carbon content was found for AOTNT/EG sample.

The photocurrent generated by unmodified $\mathrm{Ti}$ and all as-anodized samples $\left(\mathrm{AOTNT} / \mathrm{H}_{2} \mathrm{O}, \mathrm{AOTNT} / \mathrm{EGH}_{2} \mathrm{O}\right.$ and AOTNT/EG) was almost negligible $\left(\sim 2 \mu \mathrm{A} / \mathrm{cm}^{2}\right)$ as they are amorphous without heat treatment. Therefore, the efficiency of generating photocurrent under halogen and UV lamp illumination in methyl orange was compared for all C5TNT/ $\mathrm{H}_{2} \mathrm{O}, \mathrm{C} 5 \mathrm{TNT} / \mathrm{EGH}_{2} \mathrm{O}$ and $\mathrm{C} 5 \mathrm{TNT} / \mathrm{EG}$ samples as shown in Figure 5. Apparently, the photocurrent generated for all samples illuminated with UV lamp was much higher than that observed with halogen lamp, demonstrating that the light from UV lamp $\left(365 \mathrm{~nm}, 11 \mathrm{~mW} / \mathrm{m}^{2}\right)$ is more efficient in generating and promoting the 
electron-hole pairs activity than a halogen lamp $\left(150 \mathrm{~mW} / \mathrm{m}^{2}\right)$. Though halogen lamp exhibits higher photointensity, however, most of the light is given out as heat instead of promoting electron-hole activity. From the DR UV-Vis analysis as shown in Figure 4, the band gap energy for $\mathrm{C} 5 \mathrm{TNT} / \mathrm{H}_{2} \mathrm{O}, \mathrm{C} 5 \mathrm{TNT} / \mathrm{EGH}_{2} \mathrm{O}$ and $\mathrm{C} 5 \mathrm{TNT} / \mathrm{EG}$ is 3.34, 3.22 and $3.15 \mathrm{eV}$, respectively. Therefore, the light from the UV lamp contains more number of photons with energy exceeding the band gap of TNT, and thus it can excite the TNT samples better compared to halogen lamp. Even though UV rays have higher energies than the light from halogen lamp, the hazardous effects possess by UV radiation is the draw back for the usage of such lamp in activating TNT.
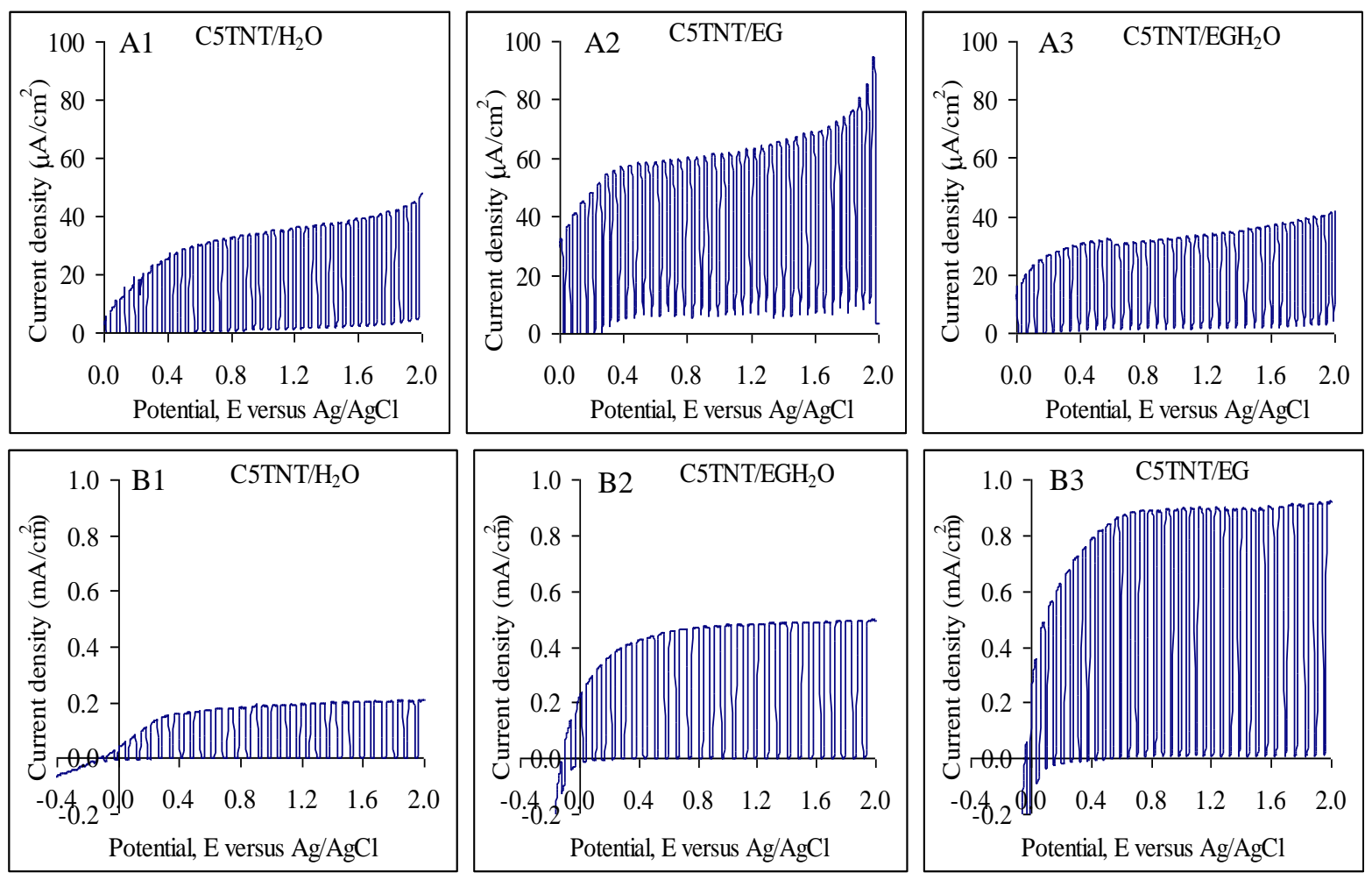

Figure 5. Comparison of the photocurrent potential curve for $\mathrm{C} 5 \mathrm{TNT} / \mathrm{H}_{2} \mathrm{O}, \mathrm{C} 5 \mathrm{TNT} / \mathrm{EGH}_{2} \mathrm{O}$ and $\mathrm{C} 5 \mathrm{TNT} / \mathrm{EG}$ under illumination of halogen lamp (A) and UV lamp (B) in $50 \mathrm{~mL} 10 \mathrm{ppm}$ methyl orange with $0.1 \mathrm{M} \mathrm{KCl}$ as supporting electrolyte

Table 3 shows the dimensional data and photocurrent current for TNT synthesized in different electrolytic medium when illuminated with UV lamp. The magnitude of photocurrent correlates to the efficiency of holes transfer at the oxide-electrolyte interface and electrons transport through nanotubes to the Ti substrate. The lowest photocurrent generated was found for $\mathrm{C} 5 \mathrm{TNT} / \mathrm{H}_{2} \mathrm{O}$ and a twofold increase on the magnitude of photocurrent was observed for C5TNT/EGH ${ }_{2} \mathrm{O}$ and the highest photocurrent was recorded for C5TNT/EG. Higher photocurrent response obtained for C5TNT/EG sample clearly indicates improved charge separation and greater electrons transport for sample with longer length and larger diameter tubes. In addition, longer length tubes also demonstrated greater surface areas that enhance the absorption of the incident photon, which in return increase the photocurrent response. However, the magnitude of photocurrent did not increase linearly with increasing length as the light intensity usually attenuates as it penetrates into the nanotubes. If the nanotubes have longer length than the effective depth of light penetration, the amount of incident photon absorb by the lower part of nanotubes will be lesser than that by the upper part. Therefore, light absorption by the TNT film will not increase further when the tube length exceeds a certain range. 

Lim et al: INVESTIGATION ON OPTICAL AND PHOTOELECTROCHEMICAL PROPERTIES OF SELF-
ASSEMBLED TITANIA NANOTUBE ARRAYS PREPARED BY ANODIZATION

Table 3. Dimensional data and photocurrent of TNT prepared in different electrolytic medium

\begin{tabular}{lccc}
\hline Sample & Diameter $(\mathbf{n m})$ & Length $(\boldsymbol{\mu m})$ & Photocurrent $^{\mathbf{a}}\left(\mathbf{m A} / \mathbf{c m}^{\mathbf{2}}\right)$ \\
\hline $\mathrm{C} 5 \mathrm{TNT} / \mathrm{H}_{2} \mathrm{O}$ & $75 \pm 9$ & $0.4 \pm 0.01$ & 0.16 \\
$\mathrm{C} 5 \mathrm{TNT} / \mathrm{EGH} \mathrm{H}_{2} \mathrm{O}$ & $99 \pm 10$ & $2.6 \pm 0.1$ & 0.47 \\
$\mathrm{C} 5 \mathrm{TNT} / \mathrm{EG}$ & $141 \pm 13$ & $11.2 \pm 0.3$ & 0.79 \\
\hline${ }^{a} \mathrm{Ph}$ &
\end{tabular}

${ }^{a}$ Photocurrent is measured at $0.5 \mathrm{~V}$ versus $\mathrm{Ag} / \mathrm{AgCl}$ in $10 \mathrm{ppm}$ methyl orange solution

Photoconversion efficiency, $\eta \%$ of light energy to chemical energy in the presence of an external applied potential for different nanotubes was calculated using Equation (2).

$$
\eta \%=\mathrm{j}_{\mathrm{ph}}\left(\frac{\left[\mathrm{E}_{\mathrm{rev}}^{\mathrm{o}}-\left|E_{\text {app }}\right|\right]}{\mathrm{I}_{\mathrm{o}}}\right) \times 100
$$

where $\mathrm{I}_{\mathrm{o}}$ is the power density of the incident light $\left(\mathrm{mW} / \mathrm{cm}^{2}\right), j_{\mathrm{ph}}$ is the photocurrent density $\left(\mathrm{mA} / \mathrm{cm}^{2}\right), E_{\text {rev }}^{\mathrm{o}}$ is the standard reversible potential for water splitting reaction which is $1.23 \mathrm{~V}$ versus NHE and the applied potential, $E_{\text {app }}$ $=\mathrm{E}_{\text {meas }}-\mathrm{E}_{\text {aoc }}$, where $\mathrm{E}_{\text {meas }}$ is the electrode potential (versus $\mathrm{Ag} / \mathrm{AgCl}$ ) of the working electrode at which photocurrent was measured under illumination and was taken as $0.5 \mathrm{~V}$ versus $\mathrm{Ag} / \mathrm{AgCl}$ in this study. $\mathrm{E}_{\text {aoc }}$ is the electrode potential (versus $\mathrm{Ag} / \mathrm{AgCl}$ ) of the same working electrode under open circuit conditions, under the same illumination, and in the same electrolyte as shown in Table 4.

Table 4. Photoelectrochemical data and photoconversion efficiency of TNT prepared in different electrolytic medium

\begin{tabular}{lccc}
\hline Sample & $\begin{array}{c}\text { Photocurrent }^{\mathbf{a}} \\
\left(\mathbf{m A} / \mathbf{c m}^{\mathbf{2}}\right)\end{array}$ & $\begin{array}{c}\mathbf{E}_{\text {aoc }} \\
(\mathbf{m V})\end{array}$ & $\begin{array}{c}\text { Photoconversion efficiency } \\
(\boldsymbol{\%})\end{array}$ \\
\hline $\mathrm{C} 5 \mathrm{TNT} / \mathrm{H}_{2} \mathrm{O}$ & 0.13 & -435 & 0.49 \\
$\mathrm{C} 5 \mathrm{TNT} / \mathrm{EGH} \mathrm{H}_{2} \mathrm{O}$ & 0.52 & -550 & 1.23 \\
$\mathrm{C} 5 \mathrm{TNT} / \mathrm{EG}$ & 1.04 & -539 & 2.79 \\
\hline
\end{tabular}

${ }^{a}$ Photocurrent was done in $0.1 \mathrm{M} \mathrm{KOH}$ at $0.5 \mathrm{~V}$ versus $\mathrm{Ag} / \mathrm{AgCl}$

As the solar cell parameters such as open circuit potential and short circuit current are best obtained from a nonpotentiostated cell configuration, therefore the assessing of the photoefficiency and the use of Equation 2 are only meant to afford figure-of-merit estimates. As shown in Table 4, the highest photoconversion efficiency was obtained for C5TNT/EG in agreement with the highest photocurrent density. Long nanotubes with ordered and welldefined morphology are necessary for good photoelectrochemical performance. The nanotube length obtained for C5TNT/EG is $11.2 \mu \mathrm{m}$, which is much longer than that for C5TNT/EGH $\mathrm{O}_{2} \mathrm{O}$ and $\mathrm{C} 5 \mathrm{TNT} / \mathrm{H}_{2} \mathrm{O}$ and therefore showed a higher photoefficiency. Other researchers have reported higher photoefficiency with nanotubes length reaching up to $220 \mu \mathrm{m}$. For example, Mor et al. [11] had demonstrated that a photoconversion efficiency of $6.8 \%$ was obtained for nanotubes formed in mixture of HF and acetic acid under UV illumination $(337 \mathrm{~nm})$. Later, TNT of $6 \mu \mathrm{m}$ length, under a similar illumination shows a photoconversion efficiency of about $12.25 \%$ [12]. $14.4 \mu \mathrm{m}$ long TNT fabricated using a formamide-based electrolyte had achieved a photoconversion efficiency of $14.42 \%$ and increased to $16.26 \%$ for $24 \mu \mathrm{m}$ long TNT fabricated in an ethylene glycol based electrolyte [13]. Nevertheless, it has been reported that the photoefficiency increased with increasing nanotube length up to $5 \mu \mathrm{m}$ and thereafter tending toward a plateau [14]. Gratzel-type solar cells were fabricated after dye sensitizing the nanotubes layers. The 
greatest overall light to electricity conversion efficiency reported for dye-sensitized solar cells based on the nanoparticles $\mathrm{TiO}_{2}$ have achieved $11 \%$ [15]. For pure nanotubes layer, the record efficiency stands at $5.2 \%$ [16] and $7 \%$ for nanotube/nanoparticles mixtures [17].

\section{Conclusion}

In summary, titania nanotube arrays were successfully synthesized via electrochemical anodization of Ti in various electrolytic compositions. Choice of electrolytic composition has an effect on the microstructure, element composition, band gap and crystal structure of TNT. In addition, photocurrent response is enhanced using the calcined nanotubes and is affected by the morphology, dimensional changes; with higher photocurrent and photoefficiency conversion is associated with smooth and longer length tube. Highest efficiency was obtained for TNT/EG than those prepared in aqueous solution.

\section{Acknowledgement}

This material is based upon work supported by the Malaysia Toray Science Foundation through S\&T research grant no. 100-RMI/PRI 16/6/2 (7/2014) and the Ministry of Education through FRGS grant no. 600-RMI/FRGS 5/3 (1/2014). The authors would also like to acknowledge Faculty of Applied Sciences, Universiti Teknologi MARA (UiTM) for the facilities provided.

\section{References}

1. Jen, H. P., Lin, M. H., Li, L. L., Wu, H. P., Huang, W. K., Cheng, P. J. and Diau, E. W. G. (2013). Highperformance large-scale flexible dye-sensitized solar cells based on anodic $\mathrm{TiO}_{2}$ nanotube arrays. ACS Materials \& Interfaces, 5(20), $10098-10104$.

2. Yu, M., Long, Y. Z., Sun, B. and Fan, Z. (2012). Recent advances in solar cells based on one-dimensional nanostructure arrays. Nanoscale, 4(9), $2783-2796$.

3. Smith, Y. R., Sarma, B., Mohanty, S. K. and Misra, M. (2013). Single-step anodization for synthesis of hierarchical $\mathrm{TiO}_{2}$ nanotube arrays on foil and wire substrate for enhanced photoelectrochemical water splitting. International Journal of Hydrogen Energy, 38(5), 2062 - 2069.

4. Liu, Y., Cheng, Y., Chen, K., Yang, G., Peng, Z., Bao, Q. and Chen, W. (2014). Enhanced light-harvesting of the conical $\mathrm{TiO}_{2}$ nanotube arrays used as the photoanodes in flexible dye-sensitized solar cells. Electrochimica Acta. 146: 838 - 844 .

5. Masuda, H. and Fukuda, K. (1995). Ordered metal nanohole arrays made by a two-step replication of honeycomb structures of anodic alumina. Science 268(5216):1466 - 1468.

6. Ruan, C., Paulose, M., Varghese, O. K., Mor, G. K. and Grimes, C. A. (2005). Fabrication of highly ordered $\mathrm{TiO}_{2}$ nanotube arrays using an organic electrolyte. Journal Physical Chemistry B 109(33):15754 - 15759.

7. Anitha, V. C., Menon, D., Nair, S. V. and Prasanth, R. (2010). Electrochemical tuning of titania nanotube morphology in inhibitor electrolytes. Electrochimica Acta 55(11):3703 - 3713.

8. Sreekantan, S., Saharudin, K., Lockman, Z. and Tzu, T. (2010). Fast-rate formation of $\mathrm{TiO}_{2}$ nanotube arrays in an organic bath and their applications in photocatalysis. Nanotechnology 21:365603.

9. Sohn, Y. S., Smith, Y. R., Misra, M. and Subramanian, V. (2008). Electrochemically assisted photocatalytic degradation of methyl orange using anodized titanium dioxide nanotubes. Applied Catalysis B: Environmental 84(3-4):372 - 378.

10. Song, X. M., Wu, J. M. and Yan, M. (2009). Photocatalytic degradation of selected dyes by titania thin films with various nanostructures. Thin Solid Films 517(15):4341 - 4347.

11. Mor, G. K., Shankar, K., Paulose, M., Varghese, O. K. and Grimes, C. A. (2005). Enhanced photocleavage of water using titania nanotube arrays. Nano Letters 5(1):191 - 195.

12. Shankar, K., Mor, G. K., Prakasam, H. E., Yoriya, S., Paulose, M., Varghese, O. K. and Grimes, C. A. (2007). Highly ordered $\mathrm{TiO}_{2}$ nanotube arrays up to $220 \mu \mathrm{m}$ in length: Use in water photoelectrolysis and dye-sensitized solar cells. Nanotechnology 18(6):065707.

13. Paulose, M., Prakasam, H. E., Varghese, O. K., Peng, L., Popat, K. C., Mor, G. K., Desai, T. A. and Grimes, C. A. (2007). $\mathrm{TiO}_{2}$ nanotube arrays of $1000 \mu \mathrm{m}$ length by anodization of titanium foil: Phenol red diffusion. Journal Physical Chemistry C 111(41):14992 - 14997. 
Lim et al: INVESTIGATION ON OPTICAL AND PHOTOELECTROCHEMICAL PROPERTIES OF SELFASSEMBLED TITANIA NANOTUBE ARRAYS PREPARED BY ANODIZATION

14. Watcharenwong, A., Chanmanee, W., de Tacconi, N. R., Chenthamarakshan, C. R., Kajitvichyanukuk, P. and Rajeshwar, K. (2007). Self-organized $\mathrm{TiO}_{2}$ nanotube arrays by anodization of Ti substrate: Effect of anodization time, voltage and medium composition on oxide morphology and photoelectrochemical response. Journal Material Research 22(11):3186 - 3195.

15. Nazeeruddin, M. K., De Angelis, F., Fantacci, S., Selloni, A., Viscardi, G., Liska, P., Ito, S., Takeru, B. and Grätzel, M. (2005). Combined Experimental and DFT-TDDFT Computational Study of Photoelectrochemical Cell Ruthenium Sensitizers. Journal American Chemical Society, 127(48):16835 - 16847.

16. Roy, P., Albu, S. P. and Schmuki, P. (2010). $\mathrm{TiO}_{2}$ nanotubes in dye-sensitized solar cells: Higher efficiencies by well-defined tube tops. Electrochemistry Communications, 12(7):949 - 951.

17. HyeokáPark, J. and GuáKang, M. (2008). Growth, detachment and transfer of highly-ordered $\mathrm{TiO}_{2}$ nanotube arrays: use in dye-sensitized solar cells. Chemical Communications, (25):2867 - 2869. 